\title{
COMPARISON OF THE VOLUME OF DISTRIBUTION, RENAL AND EXTRARENAL CLEARANCES OF INULIN AND MANNITOL IN MAN ${ }^{1}$
}

\author{
BY IRVING L. SCHWARTZ,2 ERNEST S. BREED, ${ }^{3}$ AND MORTON H. MAXWELL 4 \\ (From the Department of Physiology, New York University College of Medicine, \\ New York)
}

(Received for publication November 21, 1949; accepted January 3, 1950)

Most studies of the volume of extracellular water depend upon the injection of a non-metabolized substance into the body and the determination of the dilution volume after the substance has been uniformly distributed. Recently the mannitol and thiosulfate space was measured by a method that is independent of the route of removal of the substance and that corrects automatically for any extrarenal disposal (1). In this method it is not required that the substance be excreted solely in the urine; the avenues of disappearance may differ from individual to individual, and, in fact, need not even be known.

Since the volume of distribution of inulin has been shown to be lower than that of any substance previously used as an indicator of the extracellular space, a series of normal individuals were studied for comparison of the inulin space with the mannitol space corrected for extrarenal loss of mannitol. In these experiments coincidental data were obtained comparing the renal clearance of inulin and mannitol and measuring the extrarenal disposal of mannitol.

\section{METHODS}

The methods of study employed have been described previously $(1,2)$. A priming injection of inulin and mannitol was followed by a constant sustaining infusion for five to six hours. Assuming a volume of distribution of 18 per cent of body weight, the prime was calculated to yield a plasma concentration of 20 to $40 \mathrm{mg}$. per cent of inulin and 100 to $200 \mathrm{mg}$. per cent of mannitol. The concentration of sustaining infusion was calculated on an assumed filtration rate. All solutions were made

1 This investigation was supported by a research grant from the Division of Research Grants and Fellowships of the National Institutes of Health, U. S. Public Health Service, and by a grant from the Commonwealth Fund.

2 National Institutes of Health Postdoctorate Research Fellow.

${ }^{8}$ Fellow in the Departments of Physiology and Surgery.

4 Fellow in the Departments of Physiology and Medicine. up in sterile pyrogen-free distilled water. Constancy of the infusion rate was maintained with a constant infusion pump, calibration of which in successive 15, 30 and 60 minute periods revealed variation of less than 1 per cent in the volume flow per minute.

The subjects were allowed a light breakfast consisting of milk and buttered toast but were kept recumbent in bed. Water was given ad libitum and approximately 20 cc. of water per kilogram of body weight were given orally before the infusion was started. Before the priming injection control blood and urine samples were obtained for determination of the plasma blank concentration, $B_{0}$, and the rate of excretion of blank in the urine, $\mathrm{U}_{\mathrm{oV}} \mathrm{V}$, which quantities were subtracted respectively from subsequent plasma concentrations and urine excretion rates. An interval of one and one-half to two hours was allowed before starting serial urine collection periods of 15 or more minutes, each involving the use of a multi-eyed catheter and bladder rinses with water and air. A sample of blood was obtained at the midpoint of each urine period and shortly before the end of the last urine period during the infusion. At completion of this last bladder washout, the infusion was discontinued, and all subsequent urine was collected for the next 18 to 24 hours. Four to nine blood samples were drawn at intervals during the first two hours of this post-infusion period. Blood samples were obtained without stasis through a retention needle in the femoral artery except in Subject 7 where samples of peripheral venous blood were drawn. Liquaemin (Hoffman-La Roche), $0.1 \mathrm{cc}$. per $10 \mathrm{cc}$. of whole blood, was used as an anticoagulant.

Inulin was determined by Harrison's modification (3) of the method of Alving, Rubin and Miller (4) and mannitol was determined by the method of Corcoran and Page (5). The plasma concentrations of inulin and mannitol were corrected for a plasma water content of 94 per cent for the determination of the volumes of distribution of inulin and mannitol.

The volume of distribution of inulin was calculated as the quantity of inulin recovered in the urine divided by the equilibrium concentration of inulin in plasma water (2). No correction was made for the quantity of inulin in the renal dead space, but this error was minimized by the mannitol-induced osmotic diuresis. The volume of distribution of mannitol was calculated as the total plasma water clearance divided by the decrement with time of the natural logarithm of the plasma concentration $(1,6)$.

Wherever the constant infusion pump was used, a sample of the infusion was analyzed for the concentra- 
TABLE I

Simultaneous total plasma clearances, renal clearances and volumes of distribution of mannitol and inulin

\begin{tabular}{|c|c|c|c|c|c|c|c|c|c|c|c|}
\hline \multirow{2}{*}{ Patient } & \multirow{2}{*}{ Sex } & \multirow{2}{*}{ Wt. } & \multicolumn{2}{|c|}{ Total plasma clearance } & \multicolumn{2}{|c|}{ Renal clearance } & \multirow{2}{*}{$\begin{array}{l}\text { Renal clear- } \\
\text { ance ratio } \\
\frac{\text { Mannitol }}{\text { Inulin }}\end{array}$} & \multicolumn{2}{|c|}{$\begin{array}{c}\text { Equilibrium concentration } \\
\text { in plasma water }\end{array}$} & \multicolumn{2}{|c|}{ Volume of distribution } \\
\hline & & & Mannitol & Inulin & Mannitol & Inulin & & Mannitol & Inulin & Mannitol & Inulin \\
\hline $\begin{array}{r}1 \\
2 \\
3 \\
4 \\
5 \\
6 \\
7 \\
8 \\
9 \\
10 \\
11 \\
12 \\
13 \\
14 \\
15 \\
16 \\
17 \\
18 \\
19 \\
20\end{array}$ & $\begin{array}{l}\mathbf{M} \\
\mathbf{M} \\
\mathbf{M} \\
\mathbf{M} \\
\mathbf{M} \\
\mathbf{M} \\
\mathbf{M} \\
\mathbf{M} \\
\mathbf{F} \\
\mathbf{F} \\
\mathbf{F} \\
\mathbf{F} \\
\mathbf{F} \\
\mathbf{F} \\
\mathbf{F} \\
\mathbf{F} \\
\mathbf{F} \\
\mathbf{F} \\
\mathbf{F} \\
\mathbf{M}\end{array}$ & $\begin{array}{c}k g . \\
68.0 \\
65.5 \\
60.0 \\
63.6 \\
62.3 \\
62.7 \\
88.6 \\
80.0 \\
81.8 \\
47.3 \\
75.4 \\
60.8 \\
38.7 \\
61.0 \\
56.8 \\
75.0 \\
51.6 \\
53.0 \\
90.9 \\
48.7\end{array}$ & $\begin{array}{r}c c . / \min . \\
99.6 \\
107.9 \\
130.8 \\
91.9 \\
120.1 \\
121.6 \\
85.0\end{array}$ & $\begin{array}{r}c c . / \min . \\
91.8 \\
106.1 \\
115.7 \\
94.6 \\
122.9 \\
117.7 \\
87.2\end{array}$ & $\begin{array}{r}c c . / \min . \\
83.5 \\
100.1 \\
112.9 \\
71.1 \\
112.9 \\
89.9 \\
78.1 \\
75.6 \\
76.6 \\
74.4 \\
45.5 \\
62.5 \\
117.8 \\
114.7 \\
116.6 \\
83.6 \\
88.5 \\
113.9 \\
159.2 \\
83.4\end{array}$ & $\begin{array}{r}c c . / \text { min. } \\
92.4 \\
106.5 \\
117.8 \\
87.4 \\
117.3 \\
115.0 \\
85.0 \\
87.0 \\
86.8 \\
81.5 \\
53.7 \\
69.1 \\
130.1 \\
125.8 \\
135.0 \\
103.5 \\
102.1 \\
121.8 \\
172.0 \\
94.4\end{array}$ & $\begin{array}{l}.903 \\
.939 \\
.958 \\
.814 \\
.963 \\
.782 \\
.920 \\
.881 \\
.854 \\
.912 \\
.868 \\
.903 \\
.915 \\
.885 \\
.856 \\
.812 \\
.870 \\
.936 \\
.926 \\
.888\end{array}$ & $\begin{array}{c}\text { mg./per cent } \\
95.7 \\
118.7 \\
146.2 \\
123.1 \\
106.5 \\
99.2 \\
183.3\end{array}$ & \begin{tabular}{|c|} 
mg./per cent \\
17.5 \\
25.5 \\
28.3 \\
22.3 \\
22.2 \\
17.7 \\
27.9
\end{tabular} & $\begin{array}{c}\text { liters } \\
11.0 \\
9.61 \\
10.4 \\
15.6 \\
9.0 \\
11.8 \\
12.5\end{array}$ & $\begin{array}{c}\text { liters } \\
10.3 \\
9.8 \\
10.3 \\
10.8 \\
8.82 \\
11.0 \\
12.0\end{array}$ \\
\hline
\end{tabular}

Clearance values represent the average of two to 10 consecutive periods and are corrected to a surface area of $1.73 \mathrm{sq}$. $\mathrm{m}$. Volumes of distribution are corrected only for a plasma water content of 94 per cent. All subjects are convalescent patients without evident abnormalities of hydration.

tion of inulin and mannitol and the pump was calibrated before and after the infusion period. The total clearance was calculated as the rate of infusion in milligrams per minute divided by the concentration in plasma at the midpoint of each urine period $(7,8)$. The extrarenal clearance of inulin and mannitol was calculated as the total clearance less the renal clearance. In some of these studies, where the rate of infusion was not sufficiently constant, only the renal clearances of inulin and mannitol were compared.

\section{RESULTS}

Volumes of distribution. As shown in Table I, the volume of distribution of inulin averaged 15.7 per cent of body weight with a range from 13.6 to 17.5 per cent. The volume of distribution of mannitol averaged 15.9 per cent of body weight with a range from 14.1 to 18.7 per cent, excluding the high value of 24.5 per cent in Subject 4 where it is probable that the total plasma clearance of mannitol decreased after the infusion was stopped, and therefore a basic condition for the determination of the mannitol space was not fulfilled. ${ }^{5}$ The max-

5 It is a fundamental assumption of the method here employed for the determination of the mannitol space that the total plasma clearance of mannitol remains constant during and after stopping the infusion $(1,6)$. imum difference between the inulin and the mannitol spaces, excepting Subject 4, was 0.8 liters. On the whole it is seen that the mannitol space and the inulin space determined simultaneously corresponded closely.

Extrarenal clearance of mannitol. The extrarenal clearance of mannitol calculated as the infusion or total clearance less the renal clearance averaged $15.4 \mathrm{cc} . / \mathrm{min} . / 1.73 \mathrm{sq} . \mathrm{m}$. with a range from 6.9 to $31.7 \mathrm{cc} . / \mathrm{min} . / 1.73 \mathrm{sq}$. $\mathrm{m}$. The rate of infusion of mannitol averaged $125.5 \mathrm{mg} . / \mathrm{min}$. as compared with an average rate of excretion in the urine (after an equilibration period of one and one-half to two hours) of $107.8 \mathrm{mg} . / \mathrm{min}$.

Renal clearance of inulin and mannitol. The renal clearance of inulin in 20 subjects averaged $104.2 \mathrm{cc} . / \mathrm{min} . / 1.73 \mathrm{sq}$. $\mathrm{m}$. whereas the renal clearance of mannitol measured simultaneously averaged $93.0 \mathrm{cc} . / \mathrm{min} . / 1.73 \mathrm{sq}$. $\mathrm{m}$. It must be noted that this series contains several hypertensive subjects and others with possible impairment of renal function. The mannitol/inulin renal clearance ratio averaged 0.89 with a standard deviation of \pm 0.048 , confirming Corcoran and Page (5), Berger, Farber and Earle.(9), Hoobler (10), and other 
observations in this laboratory. All of the foregoing renal clearance comparison data were obtained during periods of constant plasma concentration maintained by a sustaining infusion.

\section{DISCUSSION}

Evidence that the inulin space closely approximates the extracellular fluid volume in man is presented elsewhere (2). The comparison study presented here represents a more critical attempt to evaluate the volume of distribution of inulin as a measure of the extracellular space.

If two inert substances of grossly different molecular proportions occupy an identical fraction of the body water, it would be unlikely for each to penetrate tissue cells to precisely the same extent. Also it is highly improbable that these substances would diffuse to precisely the same relative extent before each had already become uniformly distributed throughout the volume of distribution. Therefore, since the volumes of distribution of inulin and mannitol correspond closely and are smaller than the volume of distribution of any other substance to which the capillary wall is permeable (11-22), we believe this volume to be the extracellular space.

Studies by others $(6,9,23,24)$ of the recovery of mannitol from the urine of normal subjects indicate an extrarenal disposal of from 10 to 20 per cent of the injected dose. It is impossible to evaluate the recoveries of 154,101 and 108 per cent reported by Elkinton (25) because of the marked variability of blank excretion in these subjects. Clark and Barker (26) concluded that there was no significant metabolism of mannitol in man after comparing the rate of infusion with the rate of excretion by the constant infusion technique of Earle and Berliner (7). This is contrary to the observations of Berger, Farber and Earle, who reported an average ratio of renal clearance to infusion clearance of 0.88 , and to our present observations where the average renal to infusion clearance ratio is 0.89 , the highest ratio being 0.94 . However, we have observed considerable variability in the extrarenal clearance of mannitol (Table I), and it is possible that in some individuals the degree of extrarenal disposal is small. The fact that the plasma concentration of mannitol is almost constant in uremic patients (27) probably represents masking of mannitol utilization by an increasing plasma blank or failure of uremic tissue to metabolize mannitol, as Elkinton suggests.

\section{SUMMARY}

1. The volumes of distribution, total plasma clearance and renal clearance of mannitol and inulin were measured simultaneously in subjects without evident abnormalities of hydration.

2. Close correspondence between the inulin space measured by the infusion-recovery method and the mannitol space measured by the infusionslope method attests the validity of both methods for measuring the extracellular fluid volume.

3. Mannitol disappears from the extracellular fluid by extrarenal as well as renal mechanisms, although in some individuals the degree of extrarenal disposal is small.

4. The mannitol/inulin renal clearance ratio averaged $0.89 \pm 0.05$ in 20 subjects.

\section{ACKNOWLEDGMENTS}

The authors are indebted to Mr. Lonnie MacDonald and Mrs. Felice N. Schwartz for assistance in this study.

\section{BIBLIOGRAPHY}

1. Schwartz, I. L., The measurement of extracellular fluid by means of a constant infusion technique without collection of urine. Am. J. Physiol., 1950, $160,526$.

2. Schwartz, I. L., Schachter, D., and Freinkel, N., The measurement of extracellular fluid in man by means of a constant infusion technique. J. Clin. Invest., 1949, 28, 1117.

3. Harrison, H. E., A modification of the diphenylamine method for determination of inulin. Proc. Soc. Exper. Biol. \& Med., 1942, 49, 111.

4. Alving, A. S., Rubin, J., and Miller, B. F., A direct colorimetric method for the determination of inulin in blood and urine. J. Biol. Chem., 1939, 127, 609.

5. Corcoran, A. C., and Page, I. H., A method for the determination of mannitol in plasma and urine. J. Biol. Chem., 1947, 170, 165.

6. Newman, E. V., Bordley, J., III, and Winternitz, J., The interrelationships of glomerular filtration rate (mannitol clearance), extracellular fluid volume, surface area of the body and plasma concentration of mannitol. Bull. Johns Hopkins Hosp., 1944, 75, 253.

7. Earle, D. P., Jr., and Berliner, R. W., A simplified clinical procedure for measurement of glomerular filtration rate and renal plasma flow. Proc. Soc. Exper. Biol. \& Med., 1946, 62, 262. 
8. Berger, E. Y., Farber, S. J., and Earle, D. P., Jr., Comparison of the constant infusion and urine collection techniques for the measurement of renal function. J. Clin. Invest., 1948, 27, 710.

9. Berger, E. Y., Farber, S. J., and Earle, D. P., Jr., Renal excretion of mannitol. Proc. Soc. Exper. Biol. \& Med., 1947, 66, 62.

10. Hoobler, S. W., cited by Berger, E. Y., Farber, S. J., and Earle, D. P., Jr., Renal excretion of mannitol. Proc. Soc. Exper. Biol. \& Med., 1947, 66, 62.

11. Kaltreider, N. L., Meneely, G. R., Allen, J. R., and Bale, W. F., Determination of the volume of the extracellular fluid of the body with radioactive sodium. J. Exper. Med., 1941, 74, 569.

12. Crandall, L. A., Jr., and Anderson, M. X., Estimation of the state of hydration of the body by the amount of water available for the solution of sodium thiocyanate. Am. J. Digest. Dis. \& Nutrition, 1934, 1, 126.

13. Elkinton, J. R., and Taffel, M., The apparent volume of distribution of sulfocyanate and of sulfanilamide in the dog. Am. J. Physiol., 1942, 138, 126.

14. Lavietes, P. H., Bourdillon, J., and Klinghoffer, $K$. A., The volume of the extracellular fluids of the body. J. Clin. Invest., 1936, 15, 261.

15. Smith, P. K., Winkler, A. W., and Schwartz, B. M., The distribution of magnesium following the parenteral administration of magnesium sulfate. J. Biol. Chem., 1939, 129, 51.

16. Brodie, B. B., Brand, E., and Leshin, S., The use of bromide as a measure of extracellular fluid. J. Biol. Chem., 1939, 130, 555.

17. Manery, J. F., and Hastings, A. B., The distribution of electrolytes in mammalian tissues. J. Biol. Chem., 1939, 127, 657.
18. Manery, J. F., and Bale, W. F., The penetration of radioactive sodium and phosphorous into the extra- and intracellular phases of tissues. Am. J. Physiol., 1941, 132, 215.

19. Manery, J. F., and Haege, L. F., The extent to which radioactive chloride penetrates tissues and its significance. Am. J. Physiol., 1941, 134, 83.

20. Winkler, A. W., Elkinton, J. R., and Eisenman, A. J., Comparison of sulfocyanate with radioactive chloride and sodium in the measurement of extracellular fluid. Am. J. Physiol., 1943, 139, 239.

21. Wilde, W. S., The chloride equilibrium in muscle. Am. J. Physiol., 1945, 143, 666.

22. Moore, F. D., Determination of total body water and solids with isotopes. Science, 1946, 104, 157.

23. Smith, W. W., Finkelstein, N., and Smith, H. W., Renal excretion of hexitols (sorbitol, mannitol, and dulcitol) and their derivatives (sorbitan, isomannide, and sorbide) and of endogenous creatinine-like chromogen in dog and man. J. Biol. Chem., 1940, 135, 231.

24. Dominguez, R., Corcoran, A. C., and Page, I. H., Mannitol: kinetics of distribution, excretion, and utilization in human beings. J. Lab. \& Clin. Med., 1947, 32, 1192.

25. Elkinton, J. R., The volume of distribution of mannitol as a measure of the volume of extracellular fluid, with a study of the mannitol method. J. Clin. Invest., 1947, 26, 1088.

26. Clark, J. K., and Barker, H. G., Is mannitol metabolized? Proc. Soc. Exper. Biol. \& Med., 1948, 69, 152.

27. Elkinton, J. R., Non-utilization of mannitol in uremic patients. Federation Proc., 1949, 8, 41. 